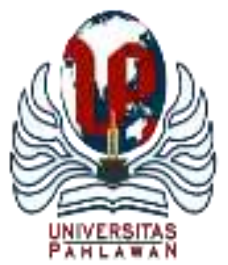

Edukatif : Jurnal Ilmu Pendidikan Volume 3 Nomor 6 Tahun 2021 Halm 3928 - 3934

EDUKATIF: JURNAL ILMU PENDIDIKAN

Research \& Learning in Education

https://edukatif.org/index.php/edukatif/index

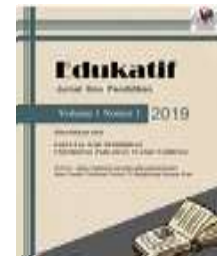

\title{
Analisis Tindak Tutur Ekspresif pada Youtube Laptop Si Unyil dan Pemanfatanya sebagai Bahan Ajar Teks Laporan Hasil Observasi di SMP
}

\author{
Wahyu Nugrahini ${ }^{1 凶}$, Dewi Herlina Sugiarti ${ }^{2}$, Uah Maspuroh ${ }^{3}$ \\ Universitas Singaperbangsa Karawang, Indonesia ${ }^{1,2,3}$ \\ E-mail : $1710631080164 @$ student.unsika.ac.id ${ }^{1}$, dewi.herlina@fkip.unsika.ac.id ${ }^{2}$, \\ uah.maspuroh@fkip.unsika.ac.id ${ }^{3}$
}

\begin{abstract}
Abstrak
Penelitian ini bertujuan untuk mendeskripsikan tindak tutur ekspresif pada youtube laptop si unyil dan pemanfaatnya sebagai bahan ajar teks laporan hasil observasi di SMP. Metode yang digunakan deskriptif kualitatif. Sumber data bersumber dari youtube kanal Edutainment Trans7 Official dan data yang dianalisis adalah berupa tuturan laptop si unyil. Teknik pengumpulan data yang digunakan yaitu teknik simak dan catat. Instrumen penelitian yaitu peneliti itu sendiri. Teknik analisis data yang digunakan adalah pengumpulan data, dan menggunaakn metode agih. Berdasarkan penelitian data yang dihasilkan berupa 51 tuturan yang terdapat pada tujuh video dan 14 tuturan ekspresif. Tuturan kebahagiaan terdapat 26 data, tuturan kebingungan terdapat 2 data, tuturan kepedasan terdapat 1 data, tuturan mengucapkan selamat terdapat 1 data, tuturan melarang terdapat 1 data, tuturan memuji terdapat 7 data, tuturan kesal terdapat 4, tuturan meminta maaf terdapat 1 data, tuturan mengajak terdapat 2 data, tuturan kerepotan terdapat 1 data, tuturan ketakutan terdapat 1 data, tuturan mengucapkan terima kasih terdapat 1 data, tuturan menyinggung terdapat 2 data, dan tuturan kaget terdapat 1 data.
\end{abstract}

Kata Kunci: pragmatik, tindak tutur ekspresif, bahan ajar.

\begin{abstract}
This study aims to describe expressive speech acts on Si Unyil's youtube laptop and its uses as teaching materials for the text of the observation report in junior high school. The method used is descriptive qualitative. The data source comes from the Edutainment Trans 7 Official youtube channel and the data analyzed is in the form of the unyil's laptop utterance. The data collection technique used is the listening and note-taking technique. The research instrument is the researcher himself. The data analysis technique used is data collection and uses the agih method. Based on the research, the data produced are 51 utterances contained in seven videos and 14 expressive utterances. There are 26 data for happiness speech, 2 data for confusion speech, 1 data for spiciness, 1 data for congratulating speech, 1 data for prohibiting speech, 7 data for praising speech, 4 data for apologizing, 1 data for apologizing, and 1 data for apologizing. In inviting there are 2 data, there is 1 data for troubled speech, 1 data for fear speech, 1 data for saying thank you, 2 data for offensive speech, and 1 data for surprised speech.
\end{abstract}

Keywords: pragmatics, expressive speech acts, teaching materials.

Copyright (c) 2021 Wahyu Nugrahini, Dewi Herlina Sugiarti, Uah Maspuroh

$\triangle$ Corresponding author:

Email : 1710631080164@student.unsika.ac.id

DOI : https://doi.org/10.31004/edukatif.v3i6.1309

ISSN 2656-8063 (Media Cetak)

ISSN 2656-8071 (Media Online)

Edukatif : Jurnal Ilmu Pendidikan Vol 3 No 6 Tahun 2021 p-ISSN 2656-8063 e-ISSN 2656-8071 
3929 Analisis Tindak Tutur Ekspresif pada Youtube Laptop Si Unyil dan Pemanfatanya sebagai Bahan Ajar Teks Laporan Hasil Observasi di SMP - Wahyu Nugrahini, Dewi Herlina Sugiarti, Uah Maspuroh DOI: https://doi.org/10.31004/edukatif.v3i6.1309

\section{PENDAHULUAN}

Manusia merupakan makhluk sosial yang tidak bisa terlepas dari peristiwa interaksi dengan sesama manusia lain, peristiwa interaksi ini sering disebut juga sebagai komunikasi. Komunikasi merupakan suatu proses penyampaian pesan yang berlangsung apabila antara penutur dan mitra tutur (penutur) memiliki kesamaan makna tentang hal yang dikomunikasikan. Peneliti menggunakan Laptop Si Unyil karena tayangan Laptop Si Unyil ini tidak hanya semata berupa tayangan yang menghibur, melainkan dapat mengedukasi para penonton yang menyaksikannya. Dengan adanya tindak tutur ekspresif dapat memberikan gambaran yang lebih signifikan dalam Laptop Si Unyil, yang nantinya pun akan menjadi materi teks laporan hasil Tindak tutur merupakan bagian dari analisis pragmatik yaitu cabang ilmu bahasa yang mengkaji bahasa berdasarkan sudut fungsionalnya harus dikaitkan dengan bentuk tutur. Wijana (Juwita, 2017) mengatakan bahwa dalam mengkomunikasikan tuturan kepada lawan tuturnya, penutur harus menuturkan hal yang relevan dengan konteks, jelas dan mudah dipahami, padat, ringkas dan selalu pada persoalan. Dalam hal ini berarti seorang penutur tidak boleh asal menuturkan tuturannya dan penuturannya sesuai dengan konteks yang telah ditentukan.

Pragmatik merupakan cabang ilmu linguistik. Pragmatik yaitu makna bahasa yang berkaitan dengan keseluruhan dari perilaku manusia, tanda-tanda atau lambang-lambang yang ada disekitarnya. Pragmatik adalah ilmu bahasa yang mempelajari pemakaian atau penggunaan bahasa, yang pada dasarnya selalu harus ditentutkan oleh konteks situasi tutur di dalam masyarakat dan wahana kebudayaan yang mewadahi dan melatar belakangi (Wibowo, 2016) Kajian pragmatik mulai memasuki dunia bahasa atau linguistik pada tahun 1970-an di Amerika (Yuliana et al., 2013). Pragmatik adalah kemampuan pemakai bahasa untuk memasang dan memilih kalimat sesuai dengan konteks, sehingga para pemakai bahasa dapat menggunakannya secara teapat (Rohmadi, 2017) Tindak tutur (speech act) merupakan segala bentuk tindak kebahasaan yang ditemukan atas konteks yang mengikuti penutur. Tindak lokusi adalah tindak tutur untuk menyatakan sesuatu. Menurut Kushartanti (Wibowo, 2018) tindak tutur juga berdefinisikan sebagai seluruh bagian bahasa dan nonbahasa yang melingkupi perbuatan bahasa yang utuh, yang berkaitan dengan peserta percakapan, bentuk penyampaian amanat, topik, dan konteks amanat itu. Dalam memahami sebuah tuturan yang merupakan tindak tutur lokusi tidak perlu dihadirkan entitas konteks, entah entitas konteks dalam pengertian apapun. Maka, tindak lokusi bisa dimaknai dengan ungakapan yang menyatakan sesuatu.

Menurut John R. Searle (Sari, 2012) menyebutkan bahwa dalam praktik penggunaan bahasa di masyarakat, terdapat setidaknya tiga macam tindak tutur yang harus dipahami bersama. Ketiga macam tindak tutur di dalam pemakaian bahasa yang sesungguhnya di masyarakat tersebut adalah tindak tutur lokusi (locutionary acts), tindak tutur ilokusi (illocutionary acts), dan tindak tutur perlokusi (perlocutionary acts). Penelitian ini akan berfokus pada tindak tutur ilokusi ekspresif. Tindak tutur ilokusi sendiri digolongkan ke dalam 5 jenis (Dwi \& Zulaeha, 2017), yaitu tindak tutur representatif, direktif, ekspresif, komisif dan deklarasi. Tuturan manusia dapat diekspresikan melalui media baik lisan maupun tulisan (Pande \& Artana, 2020). Di dalam media lisan, pihak yang melakukan tindak tutur adalah penutur (pembicara) dan mitra tuturnya (pendengar), sedangkan dalam media tulis, tuturan disampaikan oleh penulis (penutur) kepada mitra tuturnya, yaitu pembaca. Oleh karena itu, tindak tutur dapat terjadi dalam media apapun yang menggunakan bahasa.

Tindak tutur ekspresif adalah ilokusi yang fungsinya untuk mengungkapkan sikap psikologis penutur terhadap keadaan yang terikat dalam ilokusi, misalnya mengucapkan terima kasih, mengucapkan bela sungkawa atau kesedihan, dan lain sebagainya (Fitriah \& Fitriani, 2017). Adapun contoh yang menyatakan kata kerja untuk digunakan dalam pemakaian tindak tutur ini dapat dicontohkan antara lain; berterima kasih, menghina, meminta maaf, memberikan salam, mengucapkan belasungkawa, dan sebagainya. Youtube adalah pionir aktivitas kreatif yang bersifat kolektif sekaligus sebagian dari media mainstream melalui internet 
3930 Analisis Tindak Tutur Ekspresif pada Youtube Laptop Si Unyil dan Pemanfatanya sebagai Bahan Ajar Teks Laporan Hasil Observasi di SMP - Wahyu Nugrahini, Dewi Herlina Sugiarti, Uah Maspuroh DOI: https://doi.org/10.31004/edukatif.v3i6.1309

(Wirga, 2016) Youtube adalah media sosial yang paling banyak diminati masyarakat dewasa ini, meningkatnya popularitas youtube didorong oleh meningkatnya nilai guna platform berbagi video pada situs tersebut. (Mujianto, 2019) Bahan ajar yang dirancang akan menjadi sebuah bahan ajar yang bersifat baku atau standar untuk digunakan sebagai sasaran dalam pengguna tertentu. Bahan ajar yang digunakan dapat bermanfaat dan memberikan pengalaman terhadap pengguna atau peserta didik, sehingga peserta didik sebagai pengguna bahan ajar dapat mempelajari isi dan materi pelajaran. Bahan ajar adalah sesuatu yang memuat informasi dan pengetahuan yang dapat dipelajari oleh pengguanya. Menurut Remilliard dan Heck (Pribadi \& Putri, 2019) bahan ajar dapat diartikan sebagai: ..."human and nonhuman materials, and facilities that can be used to ease, encourage, improved and promote teaching and learning activities... instructional materials are defined as resources that organize and support instruction such as text books, task, and supplementary resources". Bahan ajar dapat berupa benda atau orang yang dapat digunakan untuk memfasilitasi berlangsungnya proses belajar. Penggunaan bahan ajar, seperti buku teks, tugas belajar, dan bahan pendukung lainnya akan dapat memudahkan, memotivasi, memperbaiki, dan meningkatkan aktivitas belajar dan pembelajaran. Guru dalam proses pembelajaran memiliki peran yang sangat penting, menurut Sanjaya (Yuliana et al., 2013) peran guru dalam pembelajaran itu sendiri antara lain sebagai sumber belajar, fasilitator, pengelola, demonstrator, pembimbing, motivator dan evaluator. Menurut Undang-undang Sistem Pendidikan Nasional No. 20 Tahun 2003 (Badelah et al., 2019) menyatakan pembelajaran adalah proses interaksi peserta didik dengan pendidik dan sumber belajar pada suatu lingkungan belajar Pembelajaran sebagai proses belajar yang dibangun oleh guru untuk mengembangkan kreatifitas berpikir yang dapat meningkatkan kemampuan berpikir siswa, serta dapat meningkatkan kemampuan mengkonstruksikan pengetahuan baru sebagai upaya meningkatkan penguasaan yang baik terhadap materi pelajaran. Dalam hal ini, penulis mengharapkan hasil analisis dapat menjadi media pengajaran dan sebagai bahan ajar yang efektif dengan menerapkan tindak tutur yang sesuai konteks pembelajaran.

Teks laporan hasil observasi adalah sebuah hasil dari penelitian yang telah dilakukan, pemerolehan data didapatkan menggunakan teknik observasi. Dari hasil data itulah yang akan dijadikan sebagai teks dan dijadikan sebuah laporan yang nantinya akan berupa hasil. Teks laporan hasil observasi adalah jenis teks yang menyuguhkan informasi umum mengenai sesuatu setelah diadakannya investigasi atau penelitian secara sistematis. Tayangan adalah sesuatu yang ditayangkan atau dipertontonkan, seperti sesuatu yang mempunyai nilai jual lebih yang memiliki audi dan visual sehingga dapat dilihat oleh indera penglihatan dan pendengaran. Pengguna media memiliki peran aktif dalam memilih dan menggunakan media, dalam hal ini, pengguna media merupakan pihak yang aktif dalam proses komunikasi. Tayangan yang berkualitas baik dan pantas untuk ditonton oleh masyarakat umum, khusunya bagi anak-anak. Salah satu bentuk tayangan berkualitas adalah memiliki nilai edukatif yang tinggi. Laptop Si Unyil merupakan salah satu program yang memiliki nilai edukatif yang memiliki nilai edukatif yang tinggi dan merupakan salah satu unggulan Trans 7(Siti \& Deni, 2019).

Berdasarkan pendahuluan yang merupakan latar belakang penelitian, maka pada penelitian ini akan dilakukan analisis tidak tutur ekspresif dari kanal youtube Laptop Si Unyil, serta hasil analisis akan digunakan sebagai bahan ajar teks laporan hasil observasi pada pengajaran tingkat Sekolah Menengah Pertama (SMP). Adapun penelitian sebelumnya dengan topik yang berkaitan adalah milik Sri Murti, et al (Murti et al., 2018) dengan judul "Tindak Tutur Ekspresif dalamFilm Kehormatan di Balik Kerudung Sutradara Tya Subiakto Satrio" yang pada hasil penelitian menyebutkan terdapat jenis tindak tutur dan fungsi tuturan ekspresif yaitu memuji dengan 3 konteks, mengucapkan terimakasih dengan dengan 3 ciri berdasarkan keadaan penutur, mengucapkan maaf 4 ciri, kebahagiaan dengan dengan 5 ciri serta mengeluh dengan 5 konteks yang mempengaruhi. Kemudian penelitian dengan judul "Analisis Tindak Tutur Ekspresif dalam Wacana Stand Up Comedy Indonesia Sesi 3 Babe Cabita di Kompas TV" milik Risang Krista et al, yang juga menjadikan media vidio sebagai bahan penelitian menghasilkan simpulan bahwa dalam menciptakan tuturan humor, komedian 
3931 Analisis Tindak Tutur Ekspresif pada Youtube Laptop Si Unyil dan Pemanfatanya sebagai Bahan Ajar Teks Laporan Hasil Observasi di SMP - Wahyu Nugrahini, Dewi Herlina Sugiarti, Uah Maspuroh DOI: https://doi.org/10.31004/edukatif.v3i6.1309

selalu mengeluarkan tuturan ekspresif dengan tujuan maksud dan tujuan tertentu (Pratama \& Utomo, 2020), serta pada saat melakukan Stand Up Comedy, Babe Cabita mengeluarkan tidak tutur ekspresif, antara lain tindak tutur mengkritik, tindak tutur mengeluh, tindak tutur memuji, tindak tutur menyalahkan dan tindak tutur menghina. Mneurut hasil analis,d alam menyampaikan tuturan humor Babe Cabita selalu bermaksud positif meskipun pada beberapa tuturan terdapat tindak tutur yang berkonotasi negatif.

\section{METODE PENELITIAN}

Metode penelitian adalah langkah untuk menemukan hasil melalui penelitian. Menurut Sugiyono (Sugiyono, 2015) mengatakan bahwa metode penelitian adalah metode yang berlandaskan pada filsafah postpositivisme, digunakan untuk meneliti pada kondisi yang alamiah, (sebagai lawannya dalam eksperimen) dimana peneliti adalah instrumen kunci, teknik pengumpulan data dilakukukan secara triangulasi (gabungan), analisis data bersifat induktif / deduktif, dan hasil penelitian kualitatif lebih menekankan makna dari pada generalisasi. Penggunaan metode deskriptif dikarenakan objek penelitian dapat dianalisis dengan mempertimbangkan gejala-gejala kebahasaan secara teliti dan seperti apa adanya dalam meneliti. Laporan penelitian berupa kutipan-kutipan data yang dideskripsikan sebagai hasil analisis penelitian. Penelitian deskriptif oleh Nazir (Fitriah \& Fitriani, 2017) juga diartikan sebagai suatu metode dalam meneliti stastus sekelompok manusia, suatu objek, suatu set kondisi, suatu sistem pemikiran, ataupun suatu kelas peristiwa pada masa sekarang.

Peneliti menganalisis tentang tindak tutur ekspresif yang terdapat dalam youtube Laptop Si Unyil. Analisis tersebut hanya difokuskan pada bentuk dan fungsinya. Penelitian ini bertujuan untuk mendeskripsikan bentuk dan fungsi tuturan ekspresif pada youtube Laptop Si Unyil. Penelitian menggunakan pendekatan deskriprif kualitatif. Penelitian kualitatif merupakan metode penelitian yang bersifat deskriptif yang menonjolkan menggunakan analisis. Sanapiah Faisal (Rijali, 2019) menjelaskan bahwa penelitian kualititaf, konspetualisasi, kategorisasi, dan deskripsi dikembangkan atas dasar "kejadian" yang diperoleh ketika kegiatan lapangan berlangsung. Oleh sebab itu, kegiatan pengumpulan data tidak bisa dipisahkan dengan kegiatan analisis data keran saling berhubungan satu sama lain. Penelitian ini merupakan penelitian kualitatif karena kegiatan pengumpulan data dan kegiatan analisis dilakukan bersamaan pada saat pemutaran vidio pada kanal youtube Laptop Si Unyil.

\section{HASIL DAN PEMBAHASAN PENELITIAN}

Berdasarkan data yang sudah diteliti oleh peneliti terdapat 51 tuturan ekspresif pada 7 video di kanal youtube Edutainment Trans7 Official, dengan judul sebagai berikut :

1. Kepoin Pabrik Pembuatan Keju Kanada (12 Mei 2020) durasi 5:01 detik, dengan jumlah fungsi 6 tuturan. Tuturan kebahagiaan terdapat 6 dan tuturan kebingungan terdapat 1.

2. Rendang Ikan Tuna Makanan Wajib di Bulan Ramadhan (25 Mei 2020) durasi 3:14 detik, dengan jumlah fungsi 6 tuturan. Tuturan kebahagiaan terdapat 4, tuturan kepedasan terdapat 1, dan tuutran mengucapkan selamat terdapat 1.

3. Kepoin Pabrik Pembuatan Cheese Dumpling (15 Mei 2020) durasi 6:39 detik, dengan jumlah fungsi 11 tuturan. Tuturan melarang terdapat 1 , tuturan memuji terdapat 1 . Tuturan kesal terdapat 3, tuturan meminta maaf terdapat 1 , tuturan mengajak terdapat 1 , tuturan kerepotan terdapat 1 , tuturan ketakutan terdapat 1 , tuturan kebahagiaan terdapat 1 , dan tuturan mengucapkan terima kasih terdapat 1.

4. Kepoin Pabrik Pembuatan Cincau Hitam (02 Mei 2020) durasi 5:35 detik, dengan jumlah fungsi 7 tuturan. Tuturan kebahagiaan terdapat 3 dan tuturan memuji terdapat 4.

5. Kepoin Pabrik Mainan Hot Wheels (23 Maret 2020) durasi 4:53 detik, dengan jumlah fungsi 2 tuturan. Tuturan kebahagiaan terdapat 2. 
3932 Analisis Tindak Tutur Ekspresif pada Youtube Laptop Si Unyil dan Pemanfatanya sebagai Bahan Ajar Teks Laporan Hasil Observasi di SMP - Wahyu Nugrahini, Dewi Herlina Sugiarti, Uah Maspuroh DOI: https://doi.org/10.31004/edukatif.v3i6.1309

6. Kepoin Pabrik Boba Kekinian di Tangerang Yang Lagi Hits Banget (20 Maret 2020) durasi 8:29 detik, dengan jumlah fungsi 11 tuturan. Tuturan kebahagiaan terdapat 6, tuturan menyinggung terdapat 2 , tuturan mengajak terdapat 1 , dan tuturan memuji terdapat 2.

7. Kepoin Pabrik Es Krim Kemasan (23 Maret 2020) durasi 4:36 detik. Dengan jumlah fungsi 8 tuturan. Tuturan kebahagiaan terdapat 6, tuturan kaget terdapat 1, dan tuturan kesal terdapat 1 .

Berdasarkan hasil penelitian yang ditemukan bahwa tuturan yang berdominan pada tayangan youtube Edutainment Trans7 Official adalah tuturan kebahagiaan terdapat 26 data, tuturan memuji terdapat 7 data, dan tuturan kesal terdapat 4 data. Contohnya sebagai berikut :

1. Tuturan kebahagiaan adalah suatu keadaan pikiran atau perasaan yang ditandai dengan kecukupan atau kesenangan, cinta, kepuasan, kenikmatan, atau kegembiraan.

Yang suka keju ayo merapat, hehe hihi... selain enak olahan susu yang satu ini juga dikenal sebagai sumber kalsium yang baik bagi tubuh.

Pada kalimat di atas menunjukan kesesuaian antara kalimat yang dituturkan dengan deksipsi tuturan kebahagiaan itu sendiri, hal ini ditunjukan dengan ajakan positif, tawa dan deksipsi positif mengenai hal yang dijelaskan.

2. Tuturan memuji adalah penutur mengutarakan pujian kepada mitra tutur untuk mengekspresikan kekaguman atas apa yang dilihat atau dirasakan. Tuturan memuji ini bertujuan untuk memuji mitra tutur atau sebaliknya. Tindak tutur ekspresif dengan indikator memuji ditandai dengan adanya tuturan dari penutur untuk memuji mitra tutur (Irma, 2020).

Bahan bakunya terbuat dari ikan yang kaya akan kandungan protein jadi perut bisa kenyang lebih lama deh.

3. Tuturan kesal adalah tuturan yang menyatakan ketidaksukaan, atau keengganan, marah, jengkel, kesal atau sesuatu yang tidak sesuai yang diharapkan oleh penutur. Tuturan marah merupakan salah satu emosi negatif yang muncul karena rasa kecewa dalam diri individu. Emosi dapat digolongkan menjadi dua kelompok, yaitu emosi positif dan emosi negatif. Emosi positif direalisasikan dalam bentuk senang, gembira, bahagia, puas, bangga, kasih, empati, simpati, dan sebagainya. Emosi negatif direalisasikan dalam bentuk kecewa, sedih, duka, menderita, marah, tertejan, benci, dan sebagainya (Ekawati, 2017).

Melani : Sisa satu nih aaa.. aduh yahh dumpling sisa satu-satunya malah jatoh lagi euhhh unyil

Kalimat di atas menunjukan bahwa Melani mengungkapkan kekesalan atas jatuhnya makanan yang sedang ia pegang.

\section{KESIMPULAN}

Berdasarkan analisis data dalam tayangan youtube Laptop Si Unyil terdapat 51 tuturan yang dianalisis dari 7 video. Tindak tutur ekspresif adalah ilokusi yang fungsinya untuk mengungkapkan sikap psikologis penutur terhadap keadaan yang terikat dalam ilokusi. Fungsi tuturan ekspresif ditemukan 14 tuturan ekspresif yaitu, tuturan kebehagiaan terdapat 26 data, tuturan kebingungan terdapat 2 data, tuturan kepedasan 1 data, tuturan mengucapkan selamat terdapat 1 data, tuturan melarang terdapat 1 data, tuturan memuji terdapat 7 data, tuturan kesal terdapat 4 data, tuturan meminta maaf 1 terdapat 1 data, tuturan mengajak terdapat 2 data, tuturan kerepotan terdapat 1 data, tuturan ketakutan terdapat 1 data, tuturan mengucapkan terima kasih terdapat 1 data, tuturan menyinggung terdapat 2 data, dan uturan kaget terdapat 1 data. Dari 14 tuturan ekspresif, tuturan kebahagiaanlah yang sering muncul karena penutur lebih meluapkan atau mengeekspresikan kebahagiaan pada saat bernarasi maupun saat berdialog dengan mitra tutur. Selanjutnya berdasarkan hasil 
3933 Analisis Tindak Tutur Ekspresif pada Youtube Laptop Si Unyil dan Pemanfatanya sebagai Bahan Ajar Teks Laporan Hasil Observasi di SMP - Wahyu Nugrahini, Dewi Herlina Sugiarti, Uah Maspuroh DOI: https://doi.org/10.31004/edukatif.v3i6.1309

penelitian ini akan dijadikan sebagai rujukan bahan ajar materi teks hasil observasi pada kelas X di SMP yang sudah melakukan validasi.

\section{UCAPAN TERIMA KASIH}

Peneliti mengucapkan terima kasih kepada Allah SWT yang telah memberika segala kenikmatan sehingga penulis dapat menyelesaikan penelitian ini, tak lupa saya mengucapkan terima kasih kepada pihakpihak yang terlibat dalam penelitian ini atas bimbingan Ibu Dewi Herlina Sugiarti, S.Pd., M.Pd., sebagai dosen pembimbing 1 dan Ibu Uah Maspuroh, S.Pd., M.Pd., sebagai dosen pembimbing 2. Dan saya ucapkan terima kasih kepada kedua orang tua atas segala do'a, dukungan, pikiran yang telah dikorbankan kepada peneliti. Dan pihak-pihak lain yang tidak bisa saya sebutkan satu per satu.

\section{DAFTAR PUSTAKA}

Badelah, B., Mahsun, M., \& Burhanuddin, B. (2019). Tindak Tutur Kesantunan Guru dan Siswa dalam Pembelajaran Bahasa Indonesia di SMP Negeri 2 Sakra: Tinjauan Pragmatik. LINGUA : Jurnal Bahasa, Sastra, Dan Pengajarannya, 16(2), 219-234. https://doi.org/10.30957/lingua.v16i2.604

Dwi, L., \& Zulaeha, I. (2017). Tindak Tutur Ekspresif Humanis dalam Interaksi Pembelajaran di SMA Negeri 1 Batang: Analisis Wacana Kelas. Seloka: Jurnal Pendidikan Bahasa Dan Sastra Indonesia, 6(2), 111122.

Ekawati, M. (2017). Kesantunan Semu Pada Tindak Tutur Ekspresif Marah Dalam Bahasa Indonesia. Jurnal Bahasa Dan Sastra, 1.

Fitriah, F., \& Fitriani, S. S. (2017). Analisis Tindak Tutur dalam Novel Marwah di Ujung Bara Karya R.H. Fitriadi. Master Bahasa Jurnal Ilmiah Pendidikan Bahasa Dan Sastra Indonesia, 5(1), 51-62.

Irma, C. N. (2020). Analisis Tindak Tutur Ekspresif Dalam Acara Seminar Mario Teguh Terbaru 2019. Jurnal Hasta Wiyata, 3(2).

Juwita, S. R. (2017). Tindak Tutur Ekspresif dan Komisif dalam Debat Calon Presiden Republik Indonesia 2019 (Studi Analisis Pragmatik). Jurnal Eduscience, 3(1), 37-48.

Mujianto, H. (2019). Pemanfaatan Youtube Sebagai Media Ajar Dalam Meningkatkan Minat dan Motivasi Belajar. Www.Journal.Uniga.Ac.Id., 5(1).

Murti, S., Nisai Muslihah, N., \& Permata Sari, I. (2018). Tindak Tutur Ekspresif dalam Film Kehormatan di Balik Kerudung Sutradara Tya Subiakto Satrio. Silampari Bisa: Jurnal Penelitian Pendidikan Bahasa Indonesia, Daerah, Dan Asing, 1(1), 17-32. https://doi.org/10.31540/silamparibisa.v1i1.7

Pande, N. K. N. N., \& Artana, N. (2020). Kajian Pragmatik Mengenai Tindak Tutur Bahasa Indonesia Dalam Unggahan Media Sosial Instagram @halostiki. ALFABETA: Jurnal Bahasa, Sastra, Dan Pembelajarannya, 3(1), 32-38. https://doi.org/10.33503/alfabeta.v3i1.766

Pratama, R. K., \& Utomo, A. P. Y. (2020). Analisis Tindak Tutur Ekspresif Dalam Wacana Stand Up Comedy Indonesia Sesi 3 Babe Cabita Di Kompas Tv. Caraka, 6(2), 90. https://doi.org/10.30738/.v6i2.7841

Pribadi, B. A., \& Putri, D. A. P. (2019). Pengembangan Bahan Ajar. In Universitas Terbuka. Tangerang.

Rijali, A. (2019). Analisis Data Kualitatif. Alhadharah: Jurnal Ilmu Dakwah, 17(33), 81. https://doi.org/10.18592/alhadharah.v17i33.2374

Rohmadi. (2017). Pragmatik Teori dan Analisis. Yuma Pustaka.

Sari, F. D. P. (2012). Tindak Tutur Dan Fungsi Tuturan Ekspresif Dalam Acara Galau Nite Di Metro Tv: Suatu Kajian Pragmatik. Skriptorium, 1(2), 1-14.

Siti, U. B., \& Deni, Y. (2019). Kepuasan Menonton Tayangan Laptop Si Unyil Di Televisi Pada Anak-anak Di Gempong Lampeuneurut Gempong. Jurnal Ilmiah Mahasiswa FISIP Unsyiah, 4(4). 
3934 Analisis Tindak Tutur Ekspresif pada Youtube Laptop Si Unyil dan Pemanfatanya sebagai Bahan Ajar Teks Laporan Hasil Observasi di SMP - Wahyu Nugrahini, Dewi Herlina Sugiarti, Uah Maspuroh DOI: https://doi.org/10.31004/edukatif.v3i6.1309

Sugiyono. (2015). Metode Penelitian Kuantitatif Kualitatif dan R\&D. Alfabeta CV.

Wibowo, S. E. (2016). Pragmatik. CV. Sarnu Untung.

Wibowo, S. E. (2018). Etnopgragmatik Bingkai Budaya Kiai Jawa. CV. Sarnu Untung.

Wirga, W. E. (2016). Analisis Konten Pada Media Sosial Video Youtube Untuk Mendukung Strategi Kampanye Politik. Jurnal Ilmiah Informatika Dan Komputer, 21(1).

Yuliana, R., Rohmadi, M., \& Suhita, R. (2013). Daya Pragmatik Tindak Tutur Guru Dalam Pembelajaran Bahasa Indonesia Pada Siswa Sekolah Menengah Pertama. BASASTRA Jurnal Penelitian Bahasa, Sastra Indonesia Dan Pengajarannya, 2(1), 1-14. 